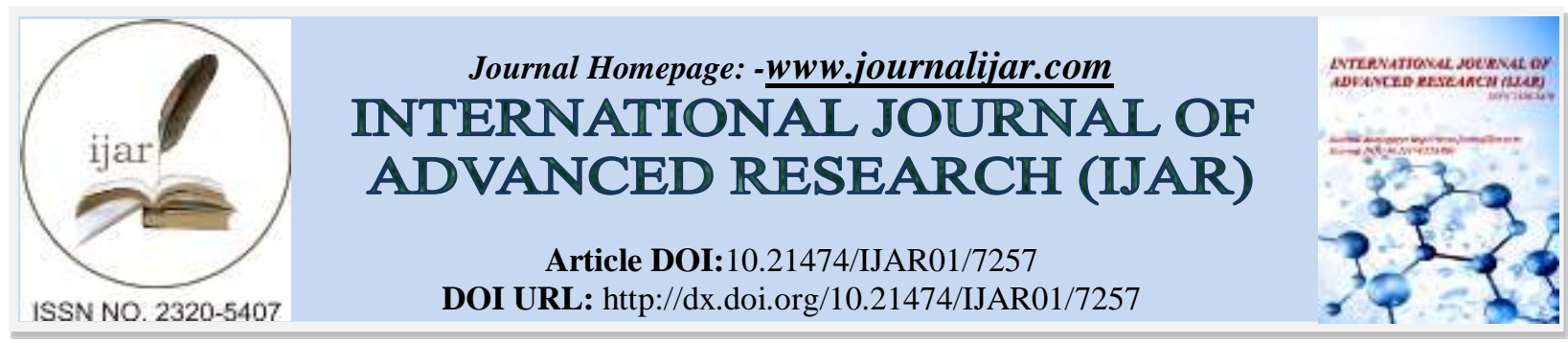

RESEARCH ARTICLE

\title{
PRE CLASS AND POST CLASS TESTS USING MULTIPLE CHOICE QUESTIONS TO IMPROVE LECTURE METHOD OF TEACHING.
}

\author{
Dr. Uma Unnikrishnan. \\ Associate Professor Department of Biochemistry Apollo Institute of Medical Sciences and Research Jubilee Hills \\ Hyderabad Telangana -500033.
}

\section{Manuscript Info}

Manuscript History

Received: 11 April 2018

Final Accepted: 13 May 2018

Published: June 2018

\section{Keywords:-}

Pre class test, Post class test ,Multiple choice questions (MCQ), Lectures

\begin{abstract}
Introduction :Medical education has witnessed a number of innovative changes in the recent past .Didactic lectures using power point presentations can be made more interesting by the faculty. Multiple choice questions (MCQ) before the class and after the class may be introduced to improve the students attention and interest.

Material and Method: A total of ten theory classes were taken on lipid metabolism for first year MBBS students. A pre class test of five MCQ and a post class test of the same MCQ were conducted. The score was noted for all the tests.

Results: The mean pre class test score was $2.69 \pm 0.33$ and mean post class test score was $4.7 \pm 0.10$ with a significance of $<0.0001$.

Conclusion : Conducting pre class and post class tests can help in changing the monotonous tone of a lecture class. A short assessment can also be done by this methodology.
\end{abstract}

Copy Right, IJAR, 2018,. All rights reserved.

\section{Introduction:-}

Studying in a medical college can be a real challenge as it requires time management, acquiring vast knowledge and shouldering many responsibilities. The pre clinical namely first year is mainly spent in classrooms listening to didactic lectures and reading textbooks ${ }^{1}$. Anatomy Physiology and Biochemistry are the three subjects in first year MBBS .Biochemistry is a difficult and abstract subject to teach as it involves many pathways with enzymatic reactions. Power point presentations is the main tool used by the teacher to convey large amount of information within one hour. Some audio and video clips are used to make lectures more interesting. Clinical cases are better understood when the students attend hospital postings. As the attention span of the students is only about 25 minutes more innovative teaching methods need to be introduced in a lecture ${ }^{2}$. Therefore in this study a pre class test of five Multiple choice questions(MCQ) and a post class test of the same MCQ relevant to the class was conducted.The objective was to make the students aware of the key points as well as perform a short term assessment within the lecture hour.

\section{Materials and Methods:-}

The study was done with 100 first year MBBS students in the Department of Biochemistry in a medical school. A total of 10 theory classes on Lipid Metabolism chapter was taken over a period of one month. In each theory class, a pre class test of 5 Multiple Choice Questions (MCQ) was conducted. This was followed by the structured lecture class with objectives and summary. 
The 5 questions were based on 1.prior knowledge of topic 2.basic understanding of concept 3.in depth knowledge of topic 4.clinically related question 5.recent advances in topic After the class the post class test with the same MCQ as pre class test was conducted. The students were then provided with the answer key for discussion. The marks for pre class and post class tests were recorded by the teacher.The same format was followed for all the 10 classes. At the end of the last class a feedback form was distributed to the students asking their opinion regarding the pre class and post class tests. A five point Likert scale was used to elicit the responses.

\section{Results:-}

The attendance of the students for all 10 classes is given in table1.

Table 1

\begin{tabular}{|l|l|l|}
\hline Classes & Topics & No: of students \\
\hline Class1: & Digestion and absorption of lipids & 85 \\
\hline Class 2: & Fat mobilization and fatty acid oxidation & 79 \\
\hline Class3: & Fatty acid synthesis & 79 \\
\hline Class 4: & $\begin{array}{l}\text { Ketone Bodies } \\
\text { metabolism }\end{array}$ & 79 \\
\hline Class 5: & $\begin{array}{l}\text { Metabolism of Triacylglycerol } \\
\text { and phospholipids }\end{array}$ & 81 \\
\hline Class 6 & Cholesterol metabolism & 71 \\
\hline Class 7 & $\begin{array}{l}\text { Cholesterol derivatives } \\
\text { Lipoproteins chemistry }\end{array}$ & 78 \\
\hline Class 8 & Lipoprotein metabolism & 75 \\
\hline Class 9 & Prostaglandin metabolism & 77 \\
\hline Class 10 & $\begin{array}{l}\text { Lipotropic factors,atherosclerosis } \\
\text { Fatty liver }\end{array}$ & 73 \\
\hline
\end{tabular}

The students marks were graded as 5 out of $5(5 / 5), 4$ out of $5(4 / 5)$ and 3 or $<3$ out of $5(3$ or $<3 / 5)$

The pre class test marks are given in table 2

Table 2:-Pre class test marks

\begin{tabular}{|l|l|l|l|}
\hline Class & $\begin{array}{l}\text { No: of Students } \\
\text { with 5/5 Marks }\end{array}$ & $\begin{array}{l}\text { No: of students } \\
\text { with 4/5 Marks }\end{array}$ & $\begin{array}{l}\text { No: of } \\
\text { students with 3 or<3/5 Marks }\end{array}$ \\
\hline Class 1 & 12 & 29 & 44 \\
\hline Class 2 & 2 & 14 & 63 \\
\hline Class 3 & 0 & 5 & 74 \\
\hline Class 4 & 5 & 26 & 48 \\
\hline Class 5 & 2 & 16 & 63 \\
\hline Class 6 & 0 & 5 & 66 \\
\hline Class 7 & 0 & 10 & 68 \\
\hline Class 8 & 4 & 12 & 59 \\
\hline Class 9 & 8 & 12 & 57 \\
\hline Class 10 & 5 & 8 & 60 \\
\hline Total & 38 & 137 & 602 \\
\hline
\end{tabular}

post class test marks are given in table 3

Table 3:-Post class test marks

\begin{tabular}{|l|l|l|l|}
\hline Class & $\begin{array}{l}\text { No: of Students } \\
\text { with 5/5 Marks }\end{array}$ & $\begin{array}{l}\text { No: of students } \\
\text { with 4/5 Marks }\end{array}$ & $\begin{array}{l}\text { No: of } \\
\text { students with 3 or<3/5 Marks }\end{array}$ \\
\hline Class 1 & 64 & 19 & 2 \\
\hline Class 2 & 61 & 14 & 4 \\
\hline Class 3 & 69 & 7 & 3 \\
\hline Class 4 & 6 & 1 \\
\hline Class 5 & 72 & 19 & 0 \\
\hline
\end{tabular}




\begin{tabular}{|l|l|l|l|}
\hline Class 6 & 43 & 23 & 5 \\
\hline Class 7 & 61 & 14 & 3 \\
\hline Class 8 & 57 & 16 & 2 \\
\hline Class 9 & 66 & 7 & 4 \\
\hline Class 10 & 56 & 15 & 2 \\
\hline Total & 612 & 140 & 26 \\
\hline
\end{tabular}

The pre class test and post class test mean, standard deviation (SD), significance In table 4

Table 4

\begin{tabular}{|l|l|l|l|}
\hline Class & $\begin{array}{l}\text { Pre class test } \\
\text { Mean } \pm \text { SD }\end{array}$ & $\begin{array}{l}\text { Post class test } \\
\text { mean } \pm \text { SD }\end{array}$ & $\begin{array}{l}\text { Significance level } \\
\text { P value }\end{array}$ \\
\hline 1 & $3.29 \pm 1.11$ & $4.71 \pm 0.54$ & $<0.0001$ \\
\hline 2 & $2.58 \pm 1.16$ & $4.68 \pm 0.70$ & $<0.0001$ \\
\hline 3 & $2.44 \pm 0.83$ & $4.81 \pm 0.57$ & $<0.0001$ \\
\hline 4 & $3.29 \pm 0.82$ & $4.90 \pm 0.34$ & $<0.0001$ \\
\hline 5 & $2.59 \pm 1.09$ & $4.76 \pm 0.42$ & $<0.0001$ \\
\hline 6 & $2.44 \pm 0.81$ & $4.47 \pm 0.80$ & $<0.0001$ \\
\hline 7 & $2.40 \pm 0.94$ & $4.71 \pm 0.68$ & $<0.0001$ \\
\hline 8 & $2.46 \pm 1.93$ & $4.72 \pm 0.55$ & $<0.0001$ \\
\hline 9 & $2.80 \pm 1.45$ & $4.70 \pm 0.68$ & $<0.0001$ \\
\hline 10 & $2.65 \pm 1.01$ & $4.71 \pm 0.56$ & $<0.0001$ \\
\hline
\end{tabular}

The final mean, standard deviation (SD),significance of all pre class and post class tests in table 5

Table 5

\begin{tabular}{|l|l|l|l|}
\hline Total classes & $\begin{array}{l}\text { Pre class test } \\
\text { Mean } \pm \text { SD }\end{array}$ & $\begin{array}{l}\text { Post class test } \\
\text { Mean } \pm \text { SD }\end{array}$ & $\begin{array}{l}\text { Significance level } \\
\text { P value }\end{array}$ \\
\hline 10 classes & $2.69 \pm 0.33$ & $4.71 \pm 0.10$ & $<0.0001$ \\
\hline
\end{tabular}

\section{Discussion:-}

The three domains to be evaluated for an undergraduate medical student are Cognitive Affective and Psychomotor. Cognitive domain can be evaluated at different levels including knowledge, comprehension, application, analysis, synthesis and evaluation ${ }^{3}$. There are many studies done to show that actively involving students in the learning process improves learning outcomes .Many teaching methods like Case based learning (CBL),Problem based learning (PBL) even horizontal and vertical teaching methods are being practiced to improve the students attention and interest ${ }^{1}$. Introduction of Multiple choice questions (MCQ) in didactic lectures can help to improve the retention of knowledge.Pre tests indicate to the students the important aspects to be concentrated on in the lecture. Pre tests help them to focus better in the class and post tests help to recall the essential points ${ }^{4}$.

In this study it was seen that a total of 38 students scored 5/5 marks in the pre class test .On the other hand a total of 612 students were able to score $5 / 5$ marks in the post class test. This increase in a perfect score clearly indicates that students are able to concentrate better on the key points. The mean pre class test score for all 10 classes was 2.69 \pm 0.33 and the mean post class test score was $4.71 \pm 0.10$ with a highly significant $p$ value of 0.0001 . In this study also it was seen that mean post class test score in all the classes was greater than the mean pre test score as shown in table 4.

These findings are similar to the study done by Jayachandran et al. However two groups namely a study and control group of students were involved in that study ${ }^{1}$ According to the study done by N. Shankar a highly significant increase in the post class test scores were noted. These assessments were compared with the year end university examination marks and a positive correlation was observed ${ }^{2}$. Similar study was done by J.Mandla in which the mean post class test scores were significantly higher than the mean pre class test scores. However a study by Hill concluded that a pre test and a post test did not result in a measurable increase in learning ${ }^{6}$. 
Lecture methodology is passive which can be made more dynamic by introducing MCQ before and after the class. Pre lecture tests help the students to determine what information is most important and which topic maybe questioned later.It increases their awareness and focus on key concepts ${ }^{7}$. Administering pre tests helps students to be more attentive and MCQ increases in depth learning of the topic. Moreover examinations for higher studies in medicine also use MCQ methodology to assess the students.

\section{Conclusion:-}

Lectures are the most common and traditional learning methods. To make a didactic lecture more effective other approaches are required.

From the present study it is clearly understood that introduction of pre class test and post class test as an assessment tool can help the undergraduate medical students to be more focused in a didactic lecture. It also helps the faculty in planning the class well paying attention to key concepts. The difference in scores between the post class test and pre class test can also be used as a short term assessment .Dividing the students into a study and control group can be done to improve the study. Comparing post test scores with the final university exam marks can be used as long term assessment.

\section{Conflict of interest and funding:- None}

\section{References:-}

1. A L Jayachandran, Balaji J. Introduction of pre and post lecture multiple choice questions for second year undergraduate medical students in microbiology: a technique to assess knowledge acquired from the lecture International Journal of Research in Medical Sciences, Feb 2016, vol 4 issue 2, pg 575.

2. Shankar N, Vallabhajosyula R. .Pre and post lecture test scores for assessment of short term effectiveness of didactic lectures in anatomy and as a predictor for performance in summative evaluation . South East Asian Journal of Medical education,2012;6(1):33-8

3. Moeen-uz Zafar Khan, Badr Muhammad Aljaralhh. Evaluation of Modified Essay Questions (MEQ)and Multiple Choice Questions (MCQ) as a tool for assessing the cognitive skills of undergraduate medical students. International Journal of Health Sciences 2011 Jan ;5(1)39-43

4. Dawane JS, Pandit VA, Dhande PP,Sahasrabudhe RA,Karandikar YSA. Comparative study of Different teaching methodologies used for developing understanding of cardiac pharmacology in undergraduate medical students .IOSR Journal of Research and Method in Education .2014 :4(3):34-8

5. Mandla J,Shaik H, Evaluation of lecture by pre and post test MCQ'S .Journal of Eduucation Technologyin Health Sciences 2016;3(3) $65-7$

6. Hill DA. Role of the pre test in the progressive assessment of medical students .Aust N Z J Surg.1992 ;62(9):743-6

7. Akila Lakshmikandhan, Balaji Ramraj Does pre test accelerate learning pattern in undergraduate medicai students ? A prospective study in a tertiary care teaching hospital in Tamilnadu.An International Journal of Pharmacology and Clinical Sciences Dec 2016 vol 5 issue 4 109-112

8. Ramrajee SN, Sable PL .Comparison of the effect of post instruction multiple choice and short answer tests on delayed retention learning .Australasia Med J.2011;4(6):332-9

9. Sanju Gajjar, Rashmi Sharma,Pradeep Kumar Manish Rana. Item and test analysis to identify Quality Multiple choice questons(MCQ1 from an assessment of Medical student of Ahmedabad,Gujarat .Indian J Community Med 2014;39(1) 17-20

10. D.K.Srinivas , B.U.Adkoli.Faculty development in medical education in India.The need of the day.Al Ameen $\mathrm{J}$ Med Sci (2009):2(1) 6-13. 